\title{
Inorganic phosphorus forms in an Oxisol under no-till after industrial and municipal residues application
}

\section{Susiane Moura Cardoso dos Santos ${ }^{1}$, João Arthur Antonangelo², Angélica Cristina Fernandes Deus $^{3}$, Leonardo Theodoro Büll ${ }^{3}$}

${ }^{1}$ Universidade Estadual de Mato Grosso do Sul, Unidade Universitária de Cassilândia, Cassilândia, Mato Grosso do Sul, Brasil. E-mail: susianemoura@yahoo.com.br

${ }^{2}$ Oklahoma State University, Department of Plant and Soil Sciences, Stillwater, Oklahoma, United States. E-mail: antonan@ostatemail.okstate.edu

${ }^{3}$ Universidade Estadual Paulista Júlio de Mesquita Filho, Campus Botucatu, Botucatu, São Paulo, Brasil. E-mail: angeldeys@hotmail.com, bull@fca.unesp.br

Received: 30/06/2018; Accepted: 29/05/2019.

\section{ABSTRACT}

Industrial and municipal residues applied to agricultural crops under no-till (NT) can promote benefits to many soil properties. The reuse of such materials reduces the supply of mineral fertilizers and provides greater economic and environmental sustainability. Besides being attenuators of soil acidity, some of these residues are excellent sources of plant nutrients such as phosphorus $(\mathrm{P})$. Understanding the dynamics of $\mathrm{P}$ arising from residues applied in tropical soils is important to assist in crops fertilization management. In this context, the objective was to quantify the inorganic $\mathrm{P}$ forms $(\mathrm{Pi})$ through the $\mathrm{P}$ fractionation in an Oxisol that received application of municipal and industrial residues. Four residues composed treatments: LC - centrifuged sewage sludge with addition of lime $(\mathrm{CaO})$; LB sewage sludge from the biodigester with the addition of polyelectrolytes; E - steel slag; and Lcal - lime mud applied at doses of $0,2,4$ and $8 \mathrm{Mg} \mathrm{ha}^{-1}$. The $\mathrm{P}$ fractionation was performed in soil samples collected at 0-5, 5-10, 10-20 and 20-40 cm layers. The LC treatment provided the highest values of anion exchange resin (AER) Pi. The residual $\mathrm{P}$ has presented stability thus does not show significant differences regarding its distribution along with the soil profile.

Keywords: residue, sewage sludge, slag, lime mud, fractionation.

\section{Formas inorgânicas de fósforo em solo sob semeadura direta após aplicações de resíduos industriais e urbanos}

\section{RESUMO}

Resíduos industriais e urbanos aplicados em cultivos agrícolas sob sistema semeadura direta (SSD) podem promover benefícios aos atributos do solo. A reutilização desses materiais reduz o aporte de fertilizantes e proporciona maior sustentabilidade ambiental e econômica. Além de atenuadores da acidez do solo, alguns desses resíduos são excelentes fontes de nutrientes de planta, como o fósforo $(\mathrm{P})$. $\mathrm{O}$ entendimento da dinâmica do $\mathrm{P}$ advindo de resíduos aplicados em solos tropicais é importante para auxiliar no manejo da adubação de culturas. Neste contexto, objetivou-se quantificar as formas inorgânicas de fósforo $(\mathrm{Pi})$, por meio do fracionamento de $\mathrm{P}$, em um Latossolo Vermelho distrófico sob SSD que recebeu aplicação de resíduos urbanos e industriais. Os tratamentos foram constituídos por quatro resíduos: LC - lodo de esgoto centrifugado com adição de cal virgem $(\mathrm{CaO})$; LB lodo de esgoto proveniente de biodigestor com adição de polieletrólitos; E - escória de aciaria; e Lcal - lama cal, aplicados nas doses $0,2,4 \mathrm{e} 8 \mathrm{Mg} \mathrm{ha}^{-1}$. O fracionamento de $\mathrm{P}$ no solo foi realizado em amostras de terra coletadas nas camadas de $0-5,5-10,10-20$ e 20-40 cm. O tratamento LC proporcionou os maiores valores de Pi proveniente da resina trocadora de ânions (RTA). O P residual apresentou estabilidade no solo, não sendo encontradas grandes diferenças na distribuição de sua fração no perfil do solo.

Palavras-chave: resíduo, lodo de esgoto, escória, lama cal, fracionamento. 


\section{Introduction}

The use of residues in agriculture has been the most promising way to promote a noble end to these materials since they are often accumulated in the environment without proper treatment or use that allows their recycling (Nascimento et al., 2004). These residues vary in composition depending on the place of their origin, the season and the hygiene process used. They improve soil chemical attributes and promote changes in their physical and biological properties. The use of sewage sludge, lime sludge and steel slag in agriculture contributes to reducing the consumption of inorganic fertilizers due to the presence of essential nutrients to plants and organic matter and, in some cases, reduces the use of liming due to their capacity in neutralizing the soil acidity (i.e., steel slag), thus denoting a reduction of costs by agriculture and a decrease of the accumulation in the producer centers (Galdos et al., 2004, CarvalhoPupatto et al., 2003).

The recycling of the sludge in agriculture is undoubtedly the best alternative when it meets the necessary requirements of heavy metals and pathogens concentrations, then favoring the development and productivity of crops. In Brazil, criteria and procedures for the agricultural use of sewage sludge generated in sewage treatment plants were defined by CONAMA Resolution No. 375, August 29, 2006 (Andrade et al., 2010).

Studies regarding nutrient dynamics and fertility management in soils under NT with residues application are still scarce on tropical soils. In soil, phosphorus occurs in different forms, characterized by different adsorption capacities. Several chemical methods, based on sequential extraction, have been proposed aiming to fractionate the phosphorus according to its availability. Soil use, phosphorus removal by plants and phosphate fertilizer applications alter the dynamics of phosphorus transformations in soil. Therefore, the $\mathrm{P}$ fractionation has been used in order to study such transformations (Chang and Jackson, 1957; Hedley et al., 1982). The method proposed by Hedley et al. (1982) has the advantage of relating the forms of phosphorus in the soil to their availability to the plants. In addition, it is able to quantify the organic phosphorus. The objective was to quantify the inorganic forms of phosphorus through the
$\mathrm{P}$ fractionation after the application of four residues in an Oxisol under NT.

\section{Material and Methods}

The work has been conducted in the experimental field of Lageado farm, belonging to the Faculty of Agronomic Sciences - FCA, Botucatu, Sao Paulo, Brazil ( $22^{\circ} 51^{\prime} \mathrm{S} ; 48^{\circ} 26^{\prime} \mathrm{W}, 740 \mathrm{~m}$ ). The soil is classified as a Rhodic Hapludox and, according to Köeppen, the predominant climate is the Cwa type, tropical of altitude with dry winter and hot rainy weather during the summer. The experiment installation was carried out in 2002 with the surface application (without incorporation) of two sewage sludges: one from biodigester and another one from centrifugation with addition of virgin lime; and two industrial residues: lime mud and steel slag, as presented by Corrêa et al. (2008). They were superficially reapplied to the soil in 2005, 2007, 2009 and 2011. The treatments were constituted by four residues: LC - sewage sludge centrifuged with addition of lime $(\mathrm{CaO})$, from Presidente Prudente's STS (Sao Paulo, Brazil); LB - sewage sludge from a biodigester with the addition of polyelectrolytes, produced by STS in Barueri (Sao Paulo, Brazil); E steel slag generated by Mannesmann; and Lcal - lime mud from the Ripasa cellulose company. The chemical characteristics of the residues are presented in Table 1. The experimental design was randomized blocks, in a $4 \times 4+1$ factorial scheme and three replications $(n=3)$, with a total of 56 experimental units where each plot was arranged in $6 \mathrm{~m}$ wide $\times 7 \mathrm{~m}$ long. The residues were applied on August 25, 2011 at four doses: 0 (control), 2, 4 and $8 \mathrm{Mg} \mathrm{ha}^{-1}$, in addition to treatment with $2 \mathrm{Mg} \mathrm{ha}^{-1}$ of lime, also superficially applied.

The $\mathrm{P}$ chemical fractionation was performed through the method developed by Hedley et al. (1982) with some modifications of Condron et al. (1985). Inorganic phosphorus $(\mathrm{Pi})$ from fractionation extracts and residual $\mathrm{P}$ were determined according to Murphy and Riley (1962). The total P from the alkaline extract was obtained by digestion with ammonium persulfate and sulfuric acid in an autoclave at $121{ }^{\circ} \mathrm{C}$ for two hours, with subsequent determination also according to Murphy and Riley (1962).

Table 1. Chemical characteristics of residues used in the experiment

\begin{tabular}{|c|c|c|c|c|c|c|c|c|c|c|c|c|c|c|c|}
\hline \multirow[t]{2}{*}{ Residue } & \multirow[t]{2}{*}{$\mathbf{C} / \mathbf{N}$} & \multirow{2}{*}{$\begin{array}{c}\mathbf{p H} \\
\mathrm{CaCl}_{2}\end{array}$} & Moisture & OM & $\mathbf{N}$ & $\mathbf{P}_{2} \mathbf{O}_{5}$ & $\mathbf{K}_{2} \mathbf{O}$ & $\mathrm{Ca}$ & Mg & $\mathbf{S}$ & $\mathrm{Na}$ & $\mathbf{C u}$ & $\mathbf{F e}$ & Mn & $\mathbf{Z n}$ \\
\hline & & & \multicolumn{9}{|c|}{ 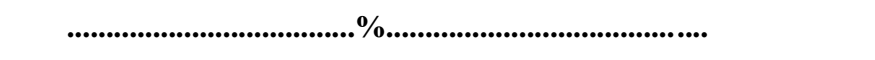 } & \multicolumn{4}{|c|}{$\ldots . . . . . . . m g ~ k g^{-1} \ldots \ldots \ldots . . . .}$. \\
\hline LC & $7 / 1$ & 8.1 & 25 & 10.5 & 0.8 & 0.4 & 0.1 & 12.1 & 0.2 & 0.1 & 270 & 75 & 4388 & 69 & 180 \\
\hline LB & $8 / 1$ & 6.8 & 18.9 & 42.1 & 3 & 3.4 & 0.1 & 1.9 & 0.4 & 0.7 & 243 & 99 & 17334 & 322 & 1176 \\
\hline Lcal & $93 / 1$ & 8.8 & 37.3 & 10.1 & 0.1 & 0.2 & 0.6 & 16.8 & 0.2 & 0 & 3263 & 6 & 265 & 91 & 9 \\
\hline $\mathbf{E}$ & $11 / 1$ & 12.4 & 10.0 & 2 & 0.1 & 1.2 & 0 & 21.8 & 2.4 & 0.9 & 684 & 23 & 145350 & 22455 & 25 \\
\hline
\end{tabular}


For this study, we considered Cross and Schlesinger (1995), who grouped the assumptions of various authors about which forms of phosphorus are extracted following the Hedley fractionation. The results were statistically analyzed by using the SISVAR software (Ferreira, 2011) and submitted to analysis of variance at $5 \%$ of probability; and the means compared by the Tukey test $(p \leq 0.05)$. Regression analysis was also performed and they contain the curves that best fitted to the model followed by their respective equations.

\section{Results and Discussion}

Regarding the soil labile phosphorus (Pi), significant differences were observed for the residues and doses applied up to 10 and $20 \mathrm{~cm}$ deep. The interactions between residues and doses were not significant. The fraction extracted by the anionic exchanging resin (AER) represents a small fraction of the total $\mathrm{P}$ contained in soils, in addition of being the fraction most influenced by the phosphate fertilization (Rheinheimer et al., 2008). This fact justifies the increase in the AER$\mathrm{Pi}$ as a function of the doses of residues applied (Table 2 ), which corroborates the results obtained in other studies (e.g.: Conte et al., 2002).

The LC residue provided higher values of $\mathrm{Pi}$ extracted by AER. In a similar way to that observed in this study, Gatiboni et al. (2007) also verified an increase of Pi due to the increase of doses of phosphate fertilizers applied. It should be noted that, although the $\mathrm{P}$ contents at this stage of the fractionation being derived from the extraction by AER, they do not represent a very close relation with those contents extracted routinely by resin, even both extractions being performed with $16 \mathrm{~h}$ agitation. Therefore, we should highlight that the extraction by the resin in the fractionation method is performed by means of strips. On the other hand, in the routine analyses, the resin in the form of small spheres is used in the extraction method (Andrade et al., 2001), which probably suggests a better exchange with soil components, then leading to more consisted results. The Pi data in AER fraction showed that, in the control, the contents decreased by increasing soil depth. Rodrigues et al. (2016) reported that under NT system, a P concentration gradient can be created, thus reducing the available $\mathrm{P}$ contents in deeper layers along with the soil profile.

None of the residues applied had any effect on the moderately labile phosphorus $\left(\mathrm{NaHCO}_{3}-\mathrm{Pi}\right)$. The $\mathrm{NaHCO}_{3}$ at $\mathrm{pH} 8.5$ extracts a portion of the $\mathrm{P}$ adsorbed to soil colloids considered labile, which means somehow available to plants. Such lability of $\mathrm{NaHCO}_{3}$ fraction is reported by the majority of the authors who worked with the $\mathrm{P}$ fractionation, indicating that the $\mathrm{Pi}$ contents extracted by AER do not represent all the soil available P (Merlin et al., 2013). The residues, as well as the interaction between factors, did not show any significant effect for the $\mathrm{NaHCO}_{3} \mathrm{Pi}$ contents. However, for the LC, in the $20-40 \mathrm{~cm}$ layer, it was found that the doses of residues linearly increased the contents of $\mathrm{NaHCO}_{3}-\mathrm{Pi}$ (Figure 1). Ceretta et al. (2010) also verified a linear increase of $\mathrm{NaHCO}_{3}$-Pi contents when applying swine manure at doses of $0,20,40$ and $80 \mathrm{~m}^{3}$ $\mathrm{ha}^{-1}$.

Table 2. Inorganic $\mathrm{P}\left(\mathrm{mg} \mathrm{kg}^{-1}\right)$ at AER and $0.1 \mathrm{M} \mathrm{NaOH}$ fractions after $\mathrm{LB}$ (sewage from biodigester), LC (sewage with lime), Lcal (lime mud) and E (steel slag) application at $0,2,4$ and $8 \mathrm{Mg} \mathrm{ha}^{-1}$ doses.

\begin{tabular}{|c|c|c|c|c|c|c|c|c|}
\hline \multicolumn{9}{|c|}{ AER Pi (mg kg-1) } \\
\hline Dose $\left(\mathrm{Mg} \mathrm{ha}^{-1}\right)$ & $\mathbf{L B}$ & $\mathbf{L C}$ & Lcal & $\mathbf{E}$ & LB & LC & Lcal & $\mathbf{E}$ \\
\hline & \multicolumn{4}{|c|}{ 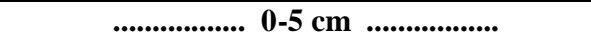 } & \multicolumn{4}{|c|}{ 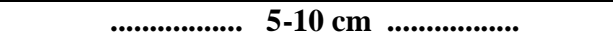 } \\
\hline $\mathbf{0}$ & 20.4 & 20.4 & 20.4 & 20.4 & 18.1 & 18.1 & 18.1 & 18.1 \\
\hline 2 & 21.0 & 23.1 & 21.7 & 20.1 & 25.1 & 20.7 & 20.2 & 15.6 \\
\hline 4 & 26.2 & 39.3 & 24.0 & 21.8 & 19.7 & 26.1 & 22.1 & 18.8 \\
\hline 8 & $26.3 b$ & $60.1 \mathrm{a}$ & $26.7 b$ & $28.8 \mathrm{~b}$ & $24.8 \mathrm{~b}$ & $42.3 \mathrm{a}$ & $23.8 \mathrm{~b}$ & $21.8 \mathrm{~b}$ \\
\hline Mean & $23.5 b$ & $35.7 \mathrm{a}$ & $23.2 b$ & $22.8 b$ & $21.9 \mathrm{ab}$ & $26.8 \mathrm{a}$ & $21.1 \mathrm{ab}$ & $18.6 \mathrm{~b}$ \\
\hline \multicolumn{9}{|c|}{$0.1 \mathrm{~mol} \mathrm{~L}^{-1} \mathrm{NaOH} \mathrm{Pi}$} \\
\hline Dose $\left(\mathrm{Mg} \mathrm{ha}^{-1}\right)$ & LB & LC & Lcal & $\mathbf{E}$ & LB & LC & Lcal & $\mathbf{E}$ \\
\hline & \multicolumn{4}{|c|}{ 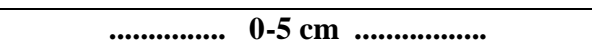 } & \multicolumn{4}{|c|}{.................. 5-10 cm .................... } \\
\hline $\mathbf{0}$ & 94.5 & 94.5 & 94.5 & 94.5 & 69.6 & 69.6 & 69.6 & 69.6 \\
\hline 2 & 83.6 & 103.5 & 85.0 & 98.1 & 70.6 & 85.2 & 76.7 & 77.6 \\
\hline 4 & 89.6 & 95.4 & 82.4 & 111.0 & 86.2 & 86.9 & 80.8 & 89.5 \\
\hline 8 & $151.6 \mathrm{a}$ & $112.7 \mathrm{~b}$ & $54.9 \mathrm{c}$ & $82.7 \mathrm{bc}$ & $115.6 \mathrm{a}$ & $96.8 \mathrm{a}$ & $48.2 \mathrm{~b}$ & $62.2 \mathrm{~b}$ \\
\hline Mean & $104.8 \mathrm{a}$ & $101.5 \mathrm{a}$ & $79.1 b$ & $96.6 \mathrm{ab}$ & $85.5 \mathrm{a}$ & $84.6 \mathrm{a}$ & $68.8 \mathrm{~b}$ & $74.7 \mathrm{ab}$ \\
\hline & \multicolumn{4}{|c|}{................ 10-20 cm .................. } & \multicolumn{4}{|c|}{.................. 20-40 cm ................... } \\
\hline $\mathbf{0}$ & 59.2 & 59.2 & 59.2 & 59.2 & $56.2^{\cdots}$ & 56.2 & 56.2 & 56.2 \\
\hline 2 & 50.0 & 68.9 & 71.4 & 76.6 & 32.3 & 38.4 & 50.0 & 44.0 \\
\hline 4 & 57.0 & 65.5 & 57.8 & 74.2 & 51.2 & 55.1 & 38.6 & 52.9 \\
\hline 8 & $86.7 \mathrm{a}$ & $83.8 \mathrm{a}$ & $44.3 \mathrm{~b}$ & $53.4 \mathrm{~b}$ & $54.2 \mathrm{ab}$ & $67.8 \mathrm{a}$ & $32.6 \mathrm{~b}$ & $34.4 \mathrm{~b}$ \\
\hline Mean & 63.2 & 69.3 & 58.2 & 65.9 & 48.5 & 54.4 & 44.4 & 46.9 \\
\hline
\end{tabular}

Means followed by the same lowercase letter (in row) are not different by Tukey test (5\%). 

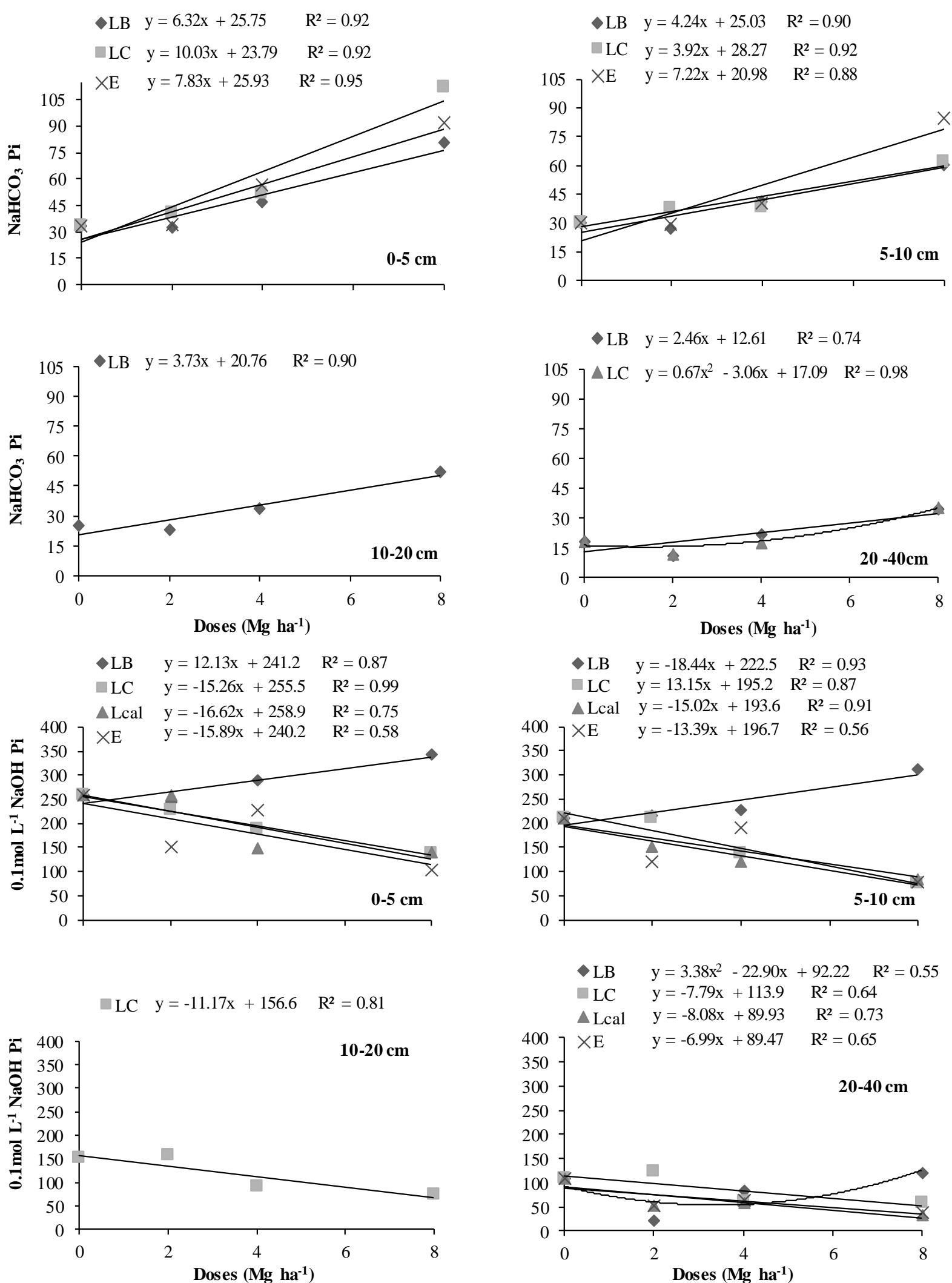

Figure 1. Inorganic $\mathrm{P}\left(\mathrm{mg} \mathrm{kg}^{-1}\right)$ from $\mathrm{NaHCO}_{3}$ and from $0.1 \mathrm{M} \mathrm{NaOH}$ after $\mathrm{LB}$ (sewage from biodigester), LC (sewage with lime), Lcal (lime mud) and $\mathrm{E}$ (steel slag) application at $0,2,4$ and $8 \mathrm{Mg} \mathrm{ha}^{-1}$ doses.

The differences found in the $\mathrm{P}$ fractionation (Table 2 and Figure 1) for the phosphorus extracted with $0.1 \mathrm{~mol}$ $\mathrm{L}^{-1} \mathrm{NaOH}\left(0.1 \mathrm{~mol} \mathrm{~L}^{-1} \mathrm{NaOH}-\mathrm{Pi}\right)$ suggest that up to the topsoil (0-5 cm layer) all the inorganic fractions of $\mathrm{P}$ were increased. On the other hand, there was a greater accumulation of $\mathrm{P}$ in less labile forms (fixed $\mathrm{P}$ ) with the increase of soil depth, as determined by the alkaline extractant $(\mathrm{NaOH})$. This is because as the depth increases, so does the concentration of $\mathrm{Fe}$ and $\mathrm{Al}$ oxides thus reducing $\mathrm{P}$ release into the soil. The $0.1 \mathrm{~mol} \mathrm{~L}^{-1}$ 
$\mathrm{NaOH}-\mathrm{Pi}$, considered moderately labile, includes the inorganic $\mathrm{P}$ not released by the previous extractant, therefore, being composed mainly of phosphates bound to $\mathrm{Fe}$ and $\mathrm{Al}$ oxy-hydroxides, probably forming monodentate and bidentate complexes (Hedley et al., 1982; Cross and Schlessinger, 1995). Some studies have shown that, in highly weathered soils, the inorganic $\mathrm{P}$ forms strongly adsorbed to the mineral fraction predominate, resulting in low levels of $\mathrm{P}$ in the soil solution, which limits the production of the crops (Novais and Smyth, 1999; Rheinheimer et al., 2008; Carneiro et al., 2011).

Regarding the $\mathrm{P}$ bound to $\mathrm{Ca}\left(1 \mathrm{~mol} \mathrm{~L}^{-1} \mathrm{HCl}-\mathrm{Pi}\right)$, it was noticed that there was a significant effect for the residues, doses, and the interaction between both in all soil layers (Table 3). The increase of $\mathrm{HCl}-\mathrm{Pi}$ with the addition of soluble phosphates can be attributed to the effect of $\mathrm{P}$ surface saturation on the adsorption sites, caused by the excessive addition of soluble phosphate fertilizer to the surface (broadcasted) of soils under NT (Conte et al. 2002). Higher $\mathrm{Ca}$ and $\mathrm{Mg}$ contents are generally found up to $20 \mathrm{~cm}$, often due to amendments applied in the topsoil under NT.

In the present study, it was attributed to the application of residues rich in those secondary nutrients (Table 1). Thus, the ease that phosphorus reacts to this available $\mathrm{Ca}$ is much greater, particularly when the $\mathrm{pH}$ is higher and, consequently, the activity of $\mathrm{Ca}^{2+}$ is high as well. Therefore, with increase in soil depth, there was a decrease in the $\mathrm{P}$ content and, consequently, in the $\mathrm{P}$ bound to $\mathrm{Ca}$ (Table 3). The levels of HCl-Pi in the soil were generally low, corroborating the results of Ceretta et al. (2010). Moreover, the addition of $E$ residue up to 8 $\mathrm{Mg} \mathrm{ha}^{-1}$, promoted an increase in the HCl-Pi (Figure 2), which may be related to the high content of $\mathrm{Ca}$ present in the residue $\mathrm{E}$ (Table 1).

The fraction of Ca-phosphate $\left(1 \mathrm{~mol} \mathrm{~L}^{-1} \mathrm{HCl}-\mathrm{Pi}\right)$ can be derived from the primary minerals of the soil formed in situ (Magid et al., 1996), and from the addition of phosphate fertilizers without previous solubilization. This fraction is an indispensable fraction in the soil for most existing $\mathrm{P}$ species. The $\mathrm{P}$ contained in this portion will only become phytoavailable if there is a reduction in $\mathrm{pH}$ values or $\mathrm{P}$ and $\mathrm{Ca}$ contents in solution. Such phenomena can be observed in the rhizosphere region, especially when there is the release of $\mathrm{H}^{+}$ions in the root exudates as a consequence of the uptake of other cations.

The 0.5 mol L ${ }^{-1} \mathrm{NaOH}-\mathrm{Pi}$ (non-labile phosphorus) behaved similarly to the fraction extracted by $0.1 \mathrm{~mol} \mathrm{~L}$

${ }^{1} \mathrm{NaOH}$ where there was a decrease for the Lcal residue up the dose of $8 \mathrm{Mg} \mathrm{ha}^{-1}$ then obtaining smaller values of Pi than those observed for the control (Table 3). The E residue application up to the dose of $8 \mathrm{Mg} \mathrm{ha}^{-1}$ provided a linear increase in the Pi contents (Figure 2). For the LC and LB residues, there was a distinct behavior of the Pi contents in the soil. For example, by increasing doses of residues, we verified a reduction of $\mathrm{Pi}$ contents with the application of LC but an increase when the LB was applied.

Table 3. Inorganic $\mathrm{P}\left(\mathrm{mg} \mathrm{kg}^{-1}\right.$ ) from $1 \mathrm{M} \mathrm{HCl}$ and $0.5 \mathrm{M} \mathrm{NaOH}$ after LB (sewage from biodigester), LC (sewage with lime), Lcal (lime mud) and E (steel slag) application at $0,2,4$ and $8 \mathrm{Mg} \mathrm{ha}^{-1}$ doses.

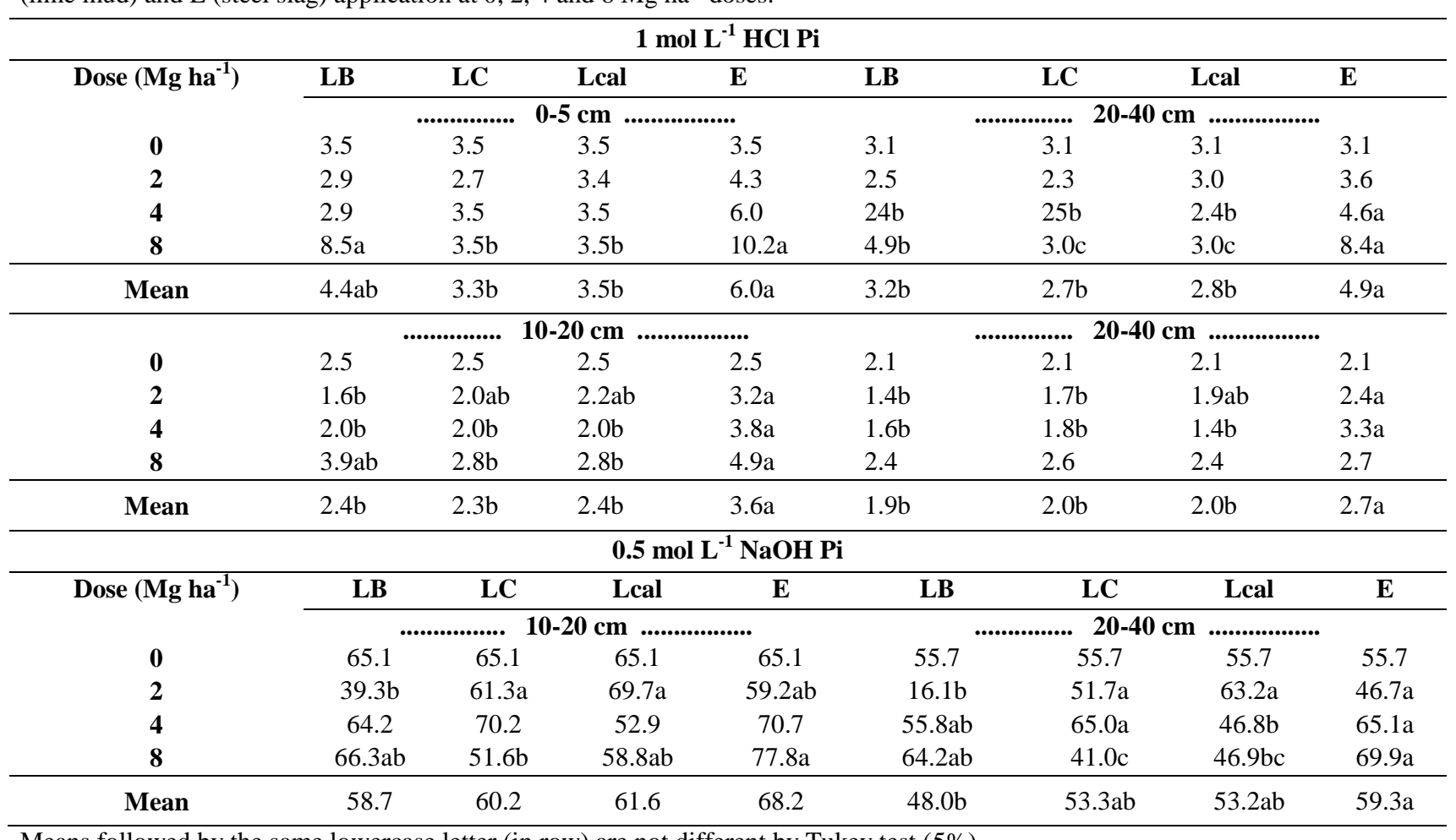

Means followed by the same lowercase letter (in row) are not different by Tukey test (5\%). 

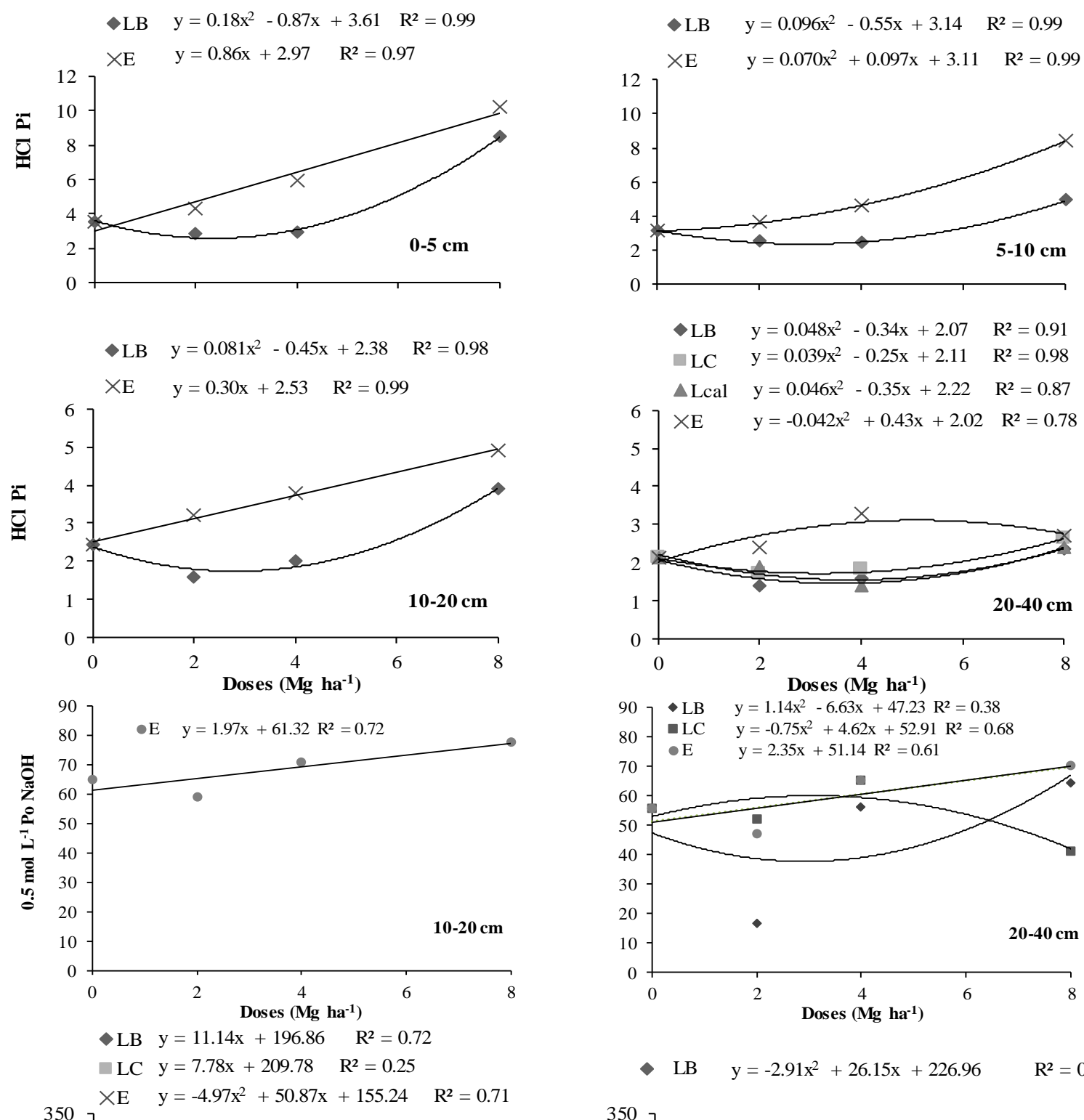

LB $\quad \mathrm{y}=-2.91 \mathrm{x}^{2}+26.15 \mathrm{x}+226.96 \quad \mathrm{R}^{2}=0.66$
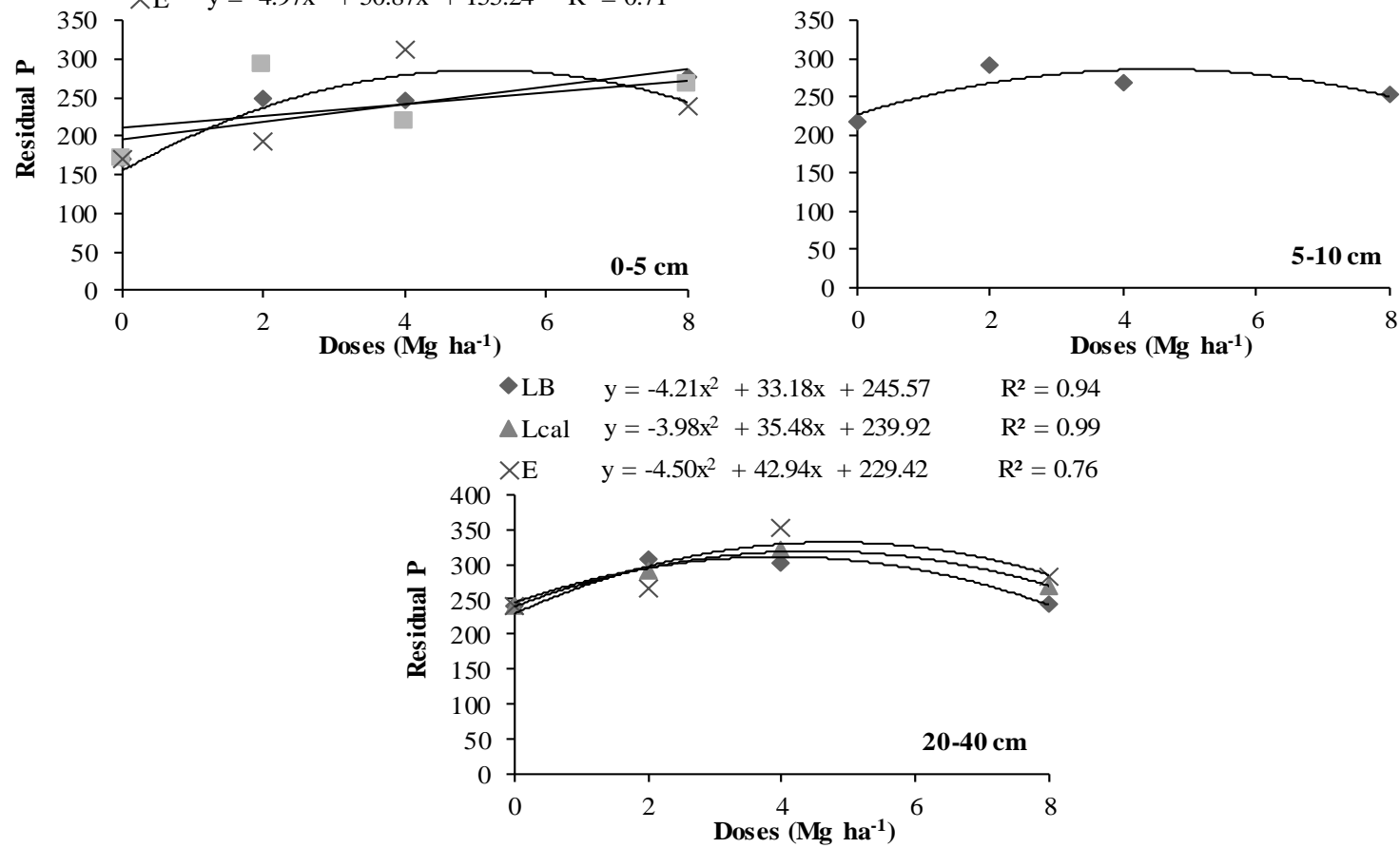

Figure 2. Inorganic $\mathrm{P}\left(\mathrm{mg} \mathrm{kg}^{-1}\right)$ from $1 \mathrm{M} \mathrm{HCl}, 0.5 \mathrm{M} \mathrm{NaOH}$ and acid digestion after $\mathrm{LB}$ (sewage from biodigester), LC (sewage with lime), Lcal (lime mud) and $\mathrm{E}$ (steel slag) application at $0,2,4$ and $8 \mathrm{Mg} \mathrm{ha}^{-1}$ doses. 
The $\mathrm{P}$ fraction in the soil extracted by $0.5 \mathrm{~mol} \mathrm{~L}^{-1}$ $\mathrm{NaOH}$ is composed by organic and inorganic forms of $\mathrm{P}$ similar to those extracted by $0.1 \mathrm{~mol} \mathrm{~L}^{-1} \mathrm{NaOH}$. However, such forms were not estimated by the extractant previously used because they were protected within the soil microaggregates (Cross and Schlesinger, 1995). Thus, the use of $0.5 \mathrm{~mol} \mathrm{~L}^{-1} \mathrm{NaOH}-\mathrm{Pi}$ only serves to complement the previous fraction, because it uses higher molarity allied to a higher agitation time (Condron et al., 1985).

In general, residual $\mathrm{Pi}$ (residual phosphorus by sulfuric digestion) had some stability with no large differences being found for its distribution along with the soil profile (Table 4). The results can be explained by the higher $\mathrm{P}$ recovery after the sequential extractions of Hedley fractionation.

It is known that $0.5 \mathrm{~mol} \mathrm{~L}^{-1} \mathrm{NaOH}$ extraction after with $1 \mathrm{~mol} \mathrm{~L}^{-1} \mathrm{HCl}$ extraction results in a higher recovery of the total $\mathrm{P}$ due to the increase in $\mathrm{NaOH}$

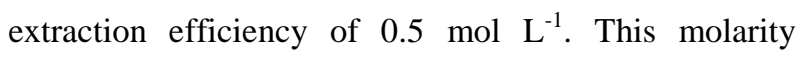
allows the organic $\mathrm{P}$ recovery in the order of 89 to $93 \%$ of the total, against 46 to $70 \%$ in the original scheme, proposed in the Hedley fractionation (Gatiboni et al., 2013).

Generally, the values of residual $\mathrm{P}$ from treatments receiving doses remained above the control and showed an increasing trend as a function of doses of residues applied. In contrast, Gatiboni et al. (2007) found that residual $\mathrm{P}$ values did not increase due to the addition of fertilizer doses. It indicates that the added phosphorus, in the case of our study, was preferentially accumulated in the higher lability fractions (Figure 2). In this fraction, inorganic and organic $\mathrm{P}$ forms of high recalcitrance are included, which generally do not participate actively in the available phosphorus, although some authors have shown that in systems with high deficiency the residual phosphorus can be a source of P to plants (Guo and Yost, 1998; Guo et al., 2000).

Table 4. Inorganic $\mathrm{P}\left(\mathrm{mg} \mathrm{kg}^{-1}\right)$ by acidic digestion after LB (sewage from biodigester), LC (sewage with lime), Lcal (lime mud) and $\mathrm{E}$ (steel slag) application at $0,2,4$ and $8 \mathrm{Mg} \mathrm{ha}^{-1}$ doses.

\begin{tabular}{|c|c|c|c|c|c|c|c|c|}
\hline \multicolumn{9}{|c|}{$P$ residual } \\
\hline Dose & LB & $\mathrm{LC}$ & Lcal & $\mathbf{E}$ & LB & LC & Lcal & $\mathbf{E}$ \\
\hline Mg ha $^{-1}$ & \multicolumn{4}{|c|}{............ 0-5 cm ........... } & \multicolumn{4}{|c|}{........... 5-10 cm ........... } \\
\hline $\mathbf{0}$ & 171.7 & 171.7 & 171.7 & 171.7 & 224.3 & 224.3 & 224.3 & 224.3 \\
\hline 2 & $249.8 \mathrm{ab}$ & $290.8 \mathrm{a}$ & $268.5 \mathrm{ab}$ & $193.3 b$ & 255.8 & 256.7 & 227.0 & 260.8 \\
\hline 4 & $245.8 \mathrm{ab}$ & $219.0 \mathrm{~b}$ & $229.8 b$ & $312.0 \mathrm{a}$ & 230.8 & 274.2 & 215.8 & 277.7 \\
\hline 8 & 276.1 & 266.7 & 250.8 & 238.5 & 257.7 & 284.0 & 230.0 & 244.8 \\
\hline \multirow[t]{8}{*}{ Mean } & 235.9 & 237.0 & 230.2 & 228.9 & $242.16 \mathrm{ab}$ & $259.8 \mathrm{a}$ & $224.3 b$ & $251.9 \mathrm{ab}$ \\
\hline & & & LB & $\mathbf{L C}$ & Lcal & $\mathbf{E}$ & & \\
\hline & \multicolumn{8}{|c|}{ 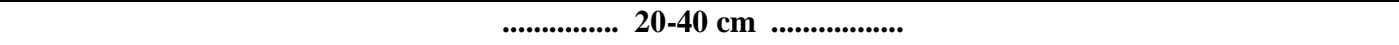 } \\
\hline & & $\mathbf{0}$ & 241.2 & 241.2 & 241.2 & 241.2 & & \\
\hline & & 2 & 306.8 & 249.2 & 291.7 & 266.0 & & \\
\hline & & 4 & $302.1 \mathrm{a}$ & $223.8 b$ & $320.7 \mathrm{a}$ & $352.7 \mathrm{a}$ & & \\
\hline & & 8 & 243.0 & 280.2 & 268.9 & 281.2 & & \\
\hline & & Mean & $273.3 \mathrm{ab}$ & $248.6 b$ & $280.5 \mathrm{ab}$ & $285.3 \mathrm{a}$ & & \\
\hline
\end{tabular}

Means followed by the same lowercase letter (in row) are not different by Tukey test (5\%).

\section{Conclusions}

1 - The LC application provides the highest values of AER Pi.

2 - The residual $\mathrm{P}$ presents stability thus does not show significant differences regarding its distribution along with the soil profile.

\section{Acknowledgements}

To the FAPESP - São Paulo Research Foundation (Registry number: 2011/12189-5) and Coordination for the Improvement of Higher Education Personnel (CAPES) for the financial support of this research.

\section{Bibliographic References}

Andrade, C.A., Boeira, R.C., Pires, A.M.M., 2010. Uso agrícola do lodo de esgoto: avaliação após resolução no. 375 do Conama, in: Coscione, A.R.C., Nogueira, T.A.N., Pires, A.M.M. Editora FEPAF, Botucatu, p. 157-170.

Andrade, J.D., Cantarella, H., Quaggio, J.A., 2001. Análise química para avaliação da fertilidade de solos tropicais. Campinas: Instituto Agronômico, 285 p.

Carneiro, L.F., Resende, A.V., Furtini Neto, A.E., Santos, J.Z.L., Curi, N., Reis, T.H.P., Valle, L.A.R., 2011. Frações de fósforo no solo em resposta à adubação fosfatada em um Latossolo com diferentes históricos de uso. Embrapa Milho e Sorgo - Artigo em periódico indexado (ALICE). 
Carvalho-Pupatto, J.G., Büll, L.T., Crusciol, C.A.C., Mauad, M., Silva, R.H.D., 2003. Efeito de escória de alto forno no crescimento radicular e na produtividade de arroz. Pesquisa Agropecuária Brasileira, 38(11), 1323-1328.

Ceretta, C.A., Lorensini, F., Brunetto, G., Girotto, E., Gatiboni, L.C., Lourenzi, C.R., Tiecher, T., Conti, L.D., Trentin, G., Miotto, A., 2010. Frações de fósforo no solo após sucessivas aplicações de dejetos de suínos em plantio direto. Área de Informação da Sede - Artigo em periódico indexado (ALICE).

Chang, S.C., Jackson, M.L., 1957. Fractionation of soil phosphorus in soils. Soil Science, Baltimore, 84(2), 133-144.

Condron, L.M., Goh, K.M., Newman, R.H., 1985. Nature and distribution of soil phosphorus as revealed by a sequential extraction method followed by $31 \mathrm{P}$ nuclear magnetic resonance analysis. Journal of Soil Science, 36(2), 199-207.

Conte, E., Anghinoni, I., Rheinheimer, D.S., 2002. Fósforo da biomassa microbiana e atividade de fosfatase ácida após aplicação de fosfato em solo no sistema plantio direto. Revista Brasileira de Ciência do Solo, 26(4), 925-930.

Corrêa, J.C., Büll, L.T., Crusciol, C.A.C., Tecchio, M.A., 2008. Aplicação superficial de escória, lama cal, lodos de esgoto e calcário na cultura da soja. Pesquisa Agropecuária Brasileira, 43(9), 1209-1219.

Cross, A.F., Schlesinger, W.H., 1995. A literature review and evaluation of the. Hedley fractionation: Applications to the biogeochemical cycle of soil phosphorus in natural ecosystems. Geoderma, 64(3-4), 197-214.

Ferreira, D.F., 2011. Sisvar: a computer statistical analysis system. Ciência e agrotecnologia, 35(6), 1039-1042.

Galdos, M.V., De Maria, I.C., Camargo, O.A., 2004. Atributos químicos e produção de milho em um Latossolo Vermelho eutroférrico tratado com lodo de esgoto. Revista Brasileira de Ciência do Solo, 28(3), 569-577.

Gatiboni, L.C., Brunetto, G., Rheinheimer, D.S., Kaminski, J., 2013. Fracionamento químico das formas de fósforo do solo: usos e limitações. Tópicos em ciência do solo, (8), 141-187.

Gatiboni, L.C., Kaminski, J., Rheinheimer, D.S., Cassol Flores, J.P., 2007. Biodisponibilidade de formas de fósforo acumuladas em solo sob sistema plantio direto. Revista Brasileira de Ciência do Solo, 31(4), 691-699.

Guo, F., Yost, R.S., 1998. Partitioning soil phosphorus into three discrete pools of differing availability. Soil Science, 163(10), 822-833.

Guo, F., Yost, R.S., Hue, N.V., Evensen, C.I., Silva, J.A., 2000. Changes in phosphorus fractions in soils under intensive plant growth. Soil Science Society of America Journal, 64(5), 1681-1689.

Hedley, M.J., Stewart, J.W.B., Chauhan, B., 1982. Changes in inorganic and organic soil phosphorus fractions induced by cultivation practices and by laboratory incubations. Soil Science Society of America Journal, 46(5), 970-976.

Magid, J., Tiessen, H., Condron, L.M., 1996. Dynamics of organic phosphorus in soils under natural and agricultural ecosystems, in: Humic substances in terrestrial ecosystems. Elsevier Science BV, 429-466.

Merlin, A., He, Z.L., Rosolem, C.A., 2013. Ruzigrass affecting soil-phosphorus availability. Pesquisa Agropecuária Brasileira, 48(12), 1583-1588.

Murphy, J.A.M.E.S., Riley, J.P., 1962. A modified single solution method for the determination of phosphate in natural waters. Analytica Chimica acta, 27, 31-36.

Nascimento, C.D., Barros, D.A.S., Melo, E.D., Oliveira, A.D., 2004. Alterações químicas em solos e crescimento de milho e feijoeiro após aplicação de lodo de esgoto. Revista Brasileira de Ciência do Solo, 28(2), 385-392.

Novais, R.D., Smyth, T.J., 1999. Fósforo em solo e planta em condições tropicais (No. 631.422 N934). Universidade Federal de Viçosa, Viçosa, MG (Brasil). Dept. de Solos, 399 p.

Rheinheimer, D.S., Gatiboni, L.C., Kaminski, J., 2008. Fatores que afetam a disponibilidade do fósforo e o manejo da adubação fosfatada em solos sob sistema plantio direto. Ciência Rural, 38(2), 576-586.

Rodrigues, M., Pavinato, P.S., Withers, P.J.A., Teles, A.P.B., Herrera, W.F.B., 2016. Legacy phosphorus and no tillage agriculture in tropical oxisols of the Brazilian savanna. Science of the Total Environment, 542, 1050-1061. 